division of Trypanosoma evansi. His observations apparently contradict the earlier ones of Roskin. In pure chemistry, Prof. Tomiček and Dr. Janský have made an exhaustive study of the methods available for determining mixed halides in connexion with the analyses of bromides and iodides in spa and thermal waters. The improvements which they have introduced enabled them to give more accurate and detailed results. It was long supposed that the waters from Darkov, Silesia, were the richest in iodine, but according to these authors the waters from Čiz in Slovakia and Bad Hall in Austria are still richer, with a total iodine content of more than $28 \mathrm{mgm}$. per litre.

\section{Colloid Aspects of Textile Materials}

A GENERAL discussion on "The Colloid Aspects of Textile Materials" has been arranged by the Faraday Society to be held in the Department of Chemistry of the University of Manchester on Sept. 21-23, under the presidency of Sir Robert Mond. An introductory address will be given by Prof. F. G. Donnan. The general subjects to be discussed include cellulose and its derivatives, lignin and keratin; fibre particles, their production, deformation, and degradation; and manufacturing processes. Among the foreign guests who will speak at the discussion are: Prof. H. Mark (Ludwigshafen), Prof. H. Staudinger (Freiburg), Dr. S. E. Sheppard (Rochester, U.S.A.), Dr. J. J. Trillat (Paris), Prof. K. Freudenberg (Heidelberg), Prof. O. Roehrich (Paris), Prof. Herzog (Berlin), Prof. J. R. Katz (Amsterdam), Mr. C. R. Nodder (Lambeg), Prof. E. Elöd (Karlsruhe), and Prof. P. Krais (Dresden). Further particulars of the meeting can be obtained from The Secretary, Faraday Society, 13 South Square, Gray's Inn, London, W.C.1.

\section{Swedish Meteorology}

The State Meteorological and Hydrographical Service of Sweden has published as Part 2 of the Ársbok for 1932 the meteorological statistics of the country for the year 1929. The data are collected from more than two hundred stations, for each of which pressure, temperature, humidity, wind direction and force, cloud, and rainfall are given in three records on every day of the year. For some forty stations, monthly and yearly means are also given for each hour of observation. There is no discussion of the data, but the usefulness of this publication is enhanced by the headings and notes being given in French as well as Swedish.

\section{Announcements}

ProF. F. Wood Jones, professor of anatomy in the University of Melbourne, will go to Peking as head of the Department of Anatomy at the Peking Union Medical College, during the absence of Prof. Davidson Black on leave in Europe and America during the next six months.

THE valuable collection of Australian Coleoptera, containing a great store of 'types', of the late Mr. A. M. Lea, who died at Adelaide on Feb. 29 (see Nature for May 28, p. 786), has recently been pur-

No. 3277, Vou. 130] chased by the Governors of the South Australian Museum, partly as a memorial of his work.

THE "Achema VII" (the German Chemical Plant Exhibition, Ausstellung für chemisches Apparatewesen), arranged by the "Dechema" (Deutsche Gesellschaft für chemisches Apparatewesen, of Seelze, Hannover), will be held at Cologne in 1933 (probably on June $2-11,1933$ ) at the same time as the conferences of the Verein Deutscher Chemiker, the Deutsche Kautschukgesellschaft, the Deutsche Brennkrafttechnische Gesellsehaft, and the Dechema. Other scientific and technical societies will also hold their annual meet. ing at Cologne during the same period.

THE following awards for the year 1932-33 have been made by the Salters' Institute of Industrial Chem. istry: Fellowships renewed to: D. J. Branscombe, University College, Exeter ; H. G. Simpson, East London College; J. L. Sweeten, St. Catherine's College, Cambridge; P. Chisholm Young, Trinity College, Cambridge. Fellowships awarded to: S. C. Britton, Pembroke College, Cambridge; E. H. T. Hoblyn, Imperial College of Science and Technology ; R. H. McDowell, Jesus College, Oxford; G. Pearce, University of Birmingham. The Salters' Institute has also awarded 107 grants-in aid to young men and women employed in chemical works, to facilitate their further studies.

Popular science book lists, 27 in number, have been prepared by a special committee of the American Association for the Advancement of Science, aided by some 300 specialists in colleges, libraries, and museums. The object of the series is to offer to the general reader reliable guidance in the choice of a few elementary science books. and in following up such reading by systematic study. The lists are annotated, and cover the whole field of elementary physics and chemistry, natural history and physiography, the history of science, and the teaching of science.

THE Arctic Institute of Leningrad has prepared a new map of the polar areas of the Soviet arctic regions. The map shows the regions discovered by recent Soviet expeditions, and has been compiled in both Russian and English.

MessRs. Watts and Co. announce the early publication of "The Universe of Science", by Prof. H. Levy, in which recent pronouncements of Sir James Jeans, Sir Arthur Eddington, and General Smuts regarding the universe are critically examined.

Appricamions are invited for the following appointments, on or before the dates mentioned :--A lecturer in metallurgy and applied chemistry at the Royal Naval College, Greenwich-The Adviser on Education, Admiralty, Whitehall, S.W.1. (Aug. 22). An assistant lecturer in engineering at the School of Mines, Treforest-The Director of Education, County Hall, Cardiff (Aug. 26). A de Beers professor of mining and surveying at the University of the Witwatersrand, Johannesburg-The Secretary, Office of the High Commissioner, South Africa House, 73 Strand, W.C.2 (Sept. 7). 